\title{
Alterations on the Activities of Ion ATPases in the Gill and Muscle of Freshwater Mussel (Unio tigridis) Exposed to Copper
}

\author{
Esin Gülnaz CANLI
}

University of Niğde Ömer Halisdemir, Faculty of Sciences and Arts, Department of Biology, Niğde, Turkey ORCID ID: Esin Gülnaz CANLI: https:// orcid.org/0000-0002-0132-3712

\begin{abstract}
Received: 07.11.2021
Accepted: 23.11 .2021

Published online: 05.12.2021

Issue published: 31.12 .2021

Abstract: Ion ATPases in the tissues of aquatic animals are sensitive to metal exposures. Mussels are filter-feeding animals and have a sedentary lifestyle that makes them good bio-indicator animals. Thus, the present study was carried out to investigate the effects of copper $(0,30,90 \mu \mathrm{g} / \mathrm{L})$ on the activities of Na-ATPase, Mg-ATPase, and Ca-ATPase in the gill and muscle of freshwater mussels (Unio tigridis) in different exposure durations $(0,7,14,21$ days). Feeding of mussels during the experiments were done with the cultured unicellular algae (Cholorella vulgaris), serving them approximately $300,000 \mathrm{algae} / \mathrm{ml}$. At the end of 21 days of exposure period, no mussel mortality was recorded. Total protein concentrations in the gill and muscle did not change significantly $(\mathrm{P}>0.05)$ in any exposure groups. Likewise, control ATPase activities did not alter significantly during different exposure periods. However, ATPase activities in the gill and muscle of mussels altered significantly $(\mathrm{P}<0.05)$ following exposure to copper, especially at the higher concentration. Although there were significant increases and decreases in the activity of Mg-ATPase in both tissues, Na-ATPase and Ca-ATPase activities did not fluctuate as there were only significant decreases at the higher exposure concentration. The present data demonstrated that copper at environmentally realistic concentrations was able to alter the activities of ion ATPases in the gill and muscle of mussels and emphasized osmoregulatory stress which mussels might face in waters contaminated with copper.
\end{abstract}

Keywords: Metal, mollusk, enzyme, osmoregulation, toxicity.

\section{Bakır Etkisinde Tatlı Su Midyelerinin (Unio tigridis) Solungaç ve Kaslarındaki İyon ATPaz Aktivitelerinin Değişimi}

\begin{abstract}
Öz: Suda yaşayan hayvanların dokularındaki iyon ATPazlar metal etkilerine karşı hassastır. Midyeler suyu filtre ederek yaşadıklarından ve yerleşik yaşam tarzları nedeniyle iyi biyoindikatör hayvanlar olarak bilinmektedir. Bu nedenle bu çalışma, tatlı su midyelerinin (Unio tigridis) solungaç ve kaslarındaki Na-ATPaz, Mg-ATPaz ve Ca-ATPaz aktiviteleri üzerine bakırın farklı derişimlerde $(0,30,90 \mu \mathrm{g} / \mathrm{L})$ ve farklı sürelerdeki $(0,7,14,21$ gün) etkilerini araştırmak amacıyla yapılmıştır. Midyeler deney süresince kültür alglerle (Cholorella vulgaris) beslenmişlerdir (300.000 alg/ml). Yirmi bir günlük deney süresi sonunda herhangi bir midye ölümü kaydedilmemiştir. Solungaç ve kastaki toplam protein düzeyleri herhangi bir deney koşulunda istatistiki olarak anlamlı $(\mathrm{P}>0.05)$ bir değişim göstermemiştir. Benzer şekilde, kontrol ATPaz aktiviteleri de farklı deney süreçlerinde anlamlı bir değişim göstermemiştir. Ancak, midyelerin solungaç ve kaslarındaki ATPaz aktiviteleri, özellikle yüksek bakır etkisinde istatistiki olarak anlamlı $(\mathrm{P}<0.05)$ azalmalar göstermiştir. Mg-ATPaz aktivitesinde her iki dokuda da anlamlı artışlar ve azalışlar görülmesine rağmen, Na-ATPaz ve Ca-ATPaz aktivitelerinde dalgalanmalar görülmemiştir. Çünkü bu enzimlerin aktivitelerinde sadece anlamlı azalmalar olmuştur. Bu deneyin verileri, çevresel olarak düşük derişimlerdeki bakıın bile midyelerin solungaç ve kaslarındaki iyon ATPazların aktivitelerini değiştirebildiğini ve midyelerin bakırla kontamine olmuş sularda karşılaşabilecekleri osmoregülasyon sistem stresini vurgulamıştır.
\end{abstract}

Anahtar kelimeler: Metal, mollusca, enzim, osmoregulasyon, toksisite.

\section{Introduction}

The final stop of all kinds of pollutants released into the environment are usually the aquatic environments. For this reason, monitoring the aquatic environments and the health of organisms living in these environments are important issues that environmental scientists care about. Although metals have been used by humans for many years, their release to the environment in large quantities started with the industrial revolution. This means that metal pollution mostly started with the beginning of the $20^{\text {th }}$ century. Clark (1989) stated that there are some differences between the terms "pollution" and "contamination" of waters. According to this, water pollution is explained as various kinds of damage to aquatic organisms as a result of direct or indirect release of metals to the environment by human activities while contamination is explained as higher metal levels in the water than normal values. In other words, contamination may give a warning signal but for pollution to occur it must have been caused by human activities and adverse effects on organisms must be observed. Since fresh waters have very small volumes compared to the seas, they can be exposed to the contaminants more than the seas, emphasizing the freshwaters are more sensitive ecological environments than seas or oceans.

It is often difficult to directly observe the effect of metal contamination on aquatic environments. For this reason, various enzymatic or non-enzymatic molecules called biomarkers are frequently used to determine the effects of pollutants. Thus, concrete data can be obtained 
about the stress experienced by aquatic organisms and their physiological state (Wood et al., 2012a; 2012b). Mussels are very important indicator organisms and are frequently used to determine environmental pollution or contamination (Nugroho \& Frank, 2012; Goswami et al., 2014; Zhou et al., 2021). The most important reasons for this are feeding strategy and sedentary lifestyle of mussels. Since they filter the water, metals in the water can be intensively taken up by mussels and transported through the food-chain, making them very important organisms for biomonitoring of waters. In order to determine the potential effects of pollution, important data can be obtained both in terms of mussel biology and as a food source for humans by performing biomarker analyses in the organs of mussels (Doyotte et al., 1997; Sukhovskaya et al., 2021). For this reason, it has been suggested that the determination of enzyme activities specific to different systems in various organs can be used as an "early warning signal" in terms of very serious damage that may occur later (Canli \& Stagg, 1996).

Studies on metal accumulation and toxicity in mussels in natural aquatic environments have demonstrated that metal accumulations in mussels are not at toxic levels, except specimens from industrial areas. Similarly, metal concentrations in tissues of control Unio tigridis were found to be very low (Canli et al., 2021), suggesting there was no considerable metal contamination in the natural environment of mussels used in the present study. Laboratory experiments have shown that exposures to metals, including copper, affect the osmoregulation system of mussels, with significant fluctuations in ion ATPase activities (Viarengo et al., 1996; Vijayavel et al., 2007; Chandurvelan et al., 2013; Jorge et al., 2013; Le et al., 2021). These studies emphasized that while metals affected the osmoregulation system in mussels, several other factors such as metal concentration, duration, chemical properties of water, and biology of the species were found to be important. Thus, this study was carried out to investigate the effects of copper on the ion ATPases in the gill and muscle of freshwater mussels $U$. tigridis. For this aim, the osmoregulation enzyme activities such as NaATPase, Mg-ATPase, and Ca-ATPase in the gill and muscle were measured following exposure to different copper concentrations (0, 30, $90 \mu \mathrm{g} / \mathrm{L})$ at different durations $(0,7,14$ and 21 days).

\section{Material and Methods}

\subsection{Experimental animals and exposure conditions}

In this study, mussels (Unio tigridis) belonging to the family Unionidae were used. Mussels were collected from Gölbaşı lake of Hatay region (36 30'17.6 "N 36² 29'10.8" E) at depths of 1-6 meters by professional divers. The collected mussels were quickly brought to the laboratory where the experiments were carried out and left for two weeks for adaptation to the new conditions ( $\mathrm{pH} ; 8.3 \pm 0.08$, total hardness; $304.2 \pm 21.2 \mathrm{mg} \mathrm{CaCO}_{3} / \mathrm{L}$, alkalinity; $195 \pm 11.4 \mathrm{mg} \mathrm{Ca}_{2} \mathrm{CO}_{3} / \mathrm{L}$, conductivity; $580 \pm 10.8 \mu \mathrm{S} / \mathrm{cm}$, temperature; $22 \pm 1.0^{\circ} \mathrm{C}$, oxygen; $6.0 \pm 1.0 \mathrm{mg} / \mathrm{L}$, light regime; $12 \mathrm{~h}$ light/12 h dark). Physical and chemical quality controls of the exposure waters were done regularly with the Thermo Scientific Orion 5-Star device. All the chemical used in the experiments were purchased from Sigma (Germany) and of analytical purity.

\subsection{Algae Culturing}

Freshwater algae (Cholorella vulgaris) were cultured in the laboratory to feed the mussels both during adaptation and experiments. Algae culture medium ( $8 \mathrm{~L}$ of $3 \mathrm{NBBM}+\mathrm{V}$ media) were mixed with air continuously and the ambient temperature was kept at $22 \pm 2^{\circ} \mathrm{C}$, enlighting them with fluorescent lamps (Philips TLM 40W/54RS) using a photoperiod of 16:8 (L:D). The irradiance level was determined using a radiation sensor LI-COR (LI-250). Algae numbers were determined daily by optical density measurements at $680 \mathrm{~nm}$ using a UV-vis spectrophotometer (Schimadzu UV-1800) and algae culturing continued for one week until reaching 1513 \pm 30 absorbance at $680 \mathrm{~nm}$. These algae were called stock algae and were used in mussel feeding.

\subsection{Experiment Protocol}

At the end of the adaptation, the mussels were distributed in glass aquariums with $33 \times 33 \times 40 \mathrm{~cm}$ dimensions containing $20 \mathrm{~L}$ of tap water. Since these distributions were made randomly, there was no significant difference between the groups in terms of weight $(30.21 \pm 1.33 \mathrm{~g})$ and length $(58.65 \pm 0.97 \mathrm{~mm})$ of mussels $(\mathrm{P}>0.05)$. Then, the mussels (12 for each group) were exposed to different concentrations of copper (as $\left.\mathrm{CuSO}_{4}\right)(0,30,90 \mu \mathrm{g} / \mathrm{L})$ for different periods $(0,7,14,21$ days $)$. Preliminary experiments showed that studied copper levels were sublethal for the mussels. During the experiments, copper concentrations in the aquariums were renewed every second day for reasons such as adhesion to the glass surface, evaporation of the water, and precipitation of copper. Mussels were fed with unicellular freshwater algae (Cholorella vulgaris) before each water change (approximately 300,000 algae/ml), serving the algae at total darkness for $5 \mathrm{~h}$. At each exposure duration, mussels were taken from the aquariums and checked whether they were alive or not. Mussels were considered alive if their shells were tightly closed. In addition, the viability of the animals was confirmed during the dissection. Then, the mussels were opened by cutting the anterior and posterior adductor muscles which connect the shells and the tissues were dissected out and stored at $-85^{\circ} \mathrm{C}$ (Esco UUS-480A) until they were used.

\subsection{Measurements of Ion ATPase Activities}

Measurements of ATPase activities in Unio tigridis were detailed in our previous paper (Canli \& Canli, 2021). According to data, Na-ATPase activity was measured at $\mathrm{Na}^{+}(100 \mathrm{mM}), \mathrm{Mg}^{2+}(4 \mathrm{mM}), \mathrm{ATP}(6 \mathrm{mM}), \mathrm{pH}$ (7), temperature $\left(37^{\circ} \mathrm{C}\right)$, incubation time $(30 \mathrm{~min})$, supernatant volume $(50 \mu \mathrm{l})$. For Ca-ATPase, all the parameters used in Na-ATPase were the same but instead of $\mathrm{Na}^{+}, 4 \mathrm{mM} \mathrm{Ca}^{2+}$ was added to the medium. Residual activities were accepted as Mg-ATPase activity. Samples were placed in a water bath $\left(37^{\circ} \mathrm{C}\right)$ with a shaker (Wise Bath WSB-30) to start the reaction. The reaction was stopped after $30 \mathrm{~min}$ with $0.5 \mathrm{ml}$ ice-cold distilled water. Determination of ATPase activity was done by the method of Atkinson et al. (1973). A series of phosphate concentrations $(50-600 \mu \mathrm{M})$ were prepared to calculate the phosphate liberated from ATP and enzyme activity and the blanks were subtracted from total absorbance obtained at $390 \mathrm{~nm}$. Protein levels were measured by the method of Lowry et al. (1951) using bovine serum as standard. Finally, ATPase activity was 
calculated as $\mu \mathrm{mol} \mathrm{Pi} / \mathrm{mg}$ protein/h.

\subsection{Statistical Analysis}

Firstly, the distributions of data were determined and appropriate statistical tests were used using a package program (SPSS 20). Nonparametric data were analyzed with Kruskal Wallis and/or Mann-Witney U test and data showing normal distribution were analyzed with One Way Anova and/or t-test. The figures demonstrating the mean and associated standard error of data were drawn with Microsoft Excel Program and statistical significance levels were indicated on the figures.

\section{Results}

During the experiments, no mortality was observed in the control or copper exposed groups. Experimental results showed that copper exposures caused significant $(\mathrm{P}<0.05)$ alterations in the osmoregulation system in the gill and muscle of mussels as there were significant decreases or increases in ATPase activities. However, there was no significant change $(\mathrm{P}>0.05)$ in ATPase activities of controls between 0-21 days. Similarly, no significant difference was observed in the feeding of mussels during the experiments. Activities of $\mathrm{Na}$-ATPase and Mg-ATPase $(\mu \mathrm{mol} \mathrm{Pi} / \mathrm{mg}$ prot. $/ \mathrm{h}$ ) in the gill of controls at day 0 were $5.01 \pm 0.49$ and $9.98 \pm 0.52$ respectively while these were $4.75 \pm 0.61$ and $11.5 \pm 0.71$ at day 21 , respectively. However, ATPase activities in the gill of mussels altered significantly $(\mathrm{P}<0.05)$ following exposure to copper, especially at the higher concentration. Although there were significant increases and decreases in the activity of Mg-ATPase in in the gill, Na-ATPase activities did not fluctuate as there were only significant decreases at the higher exposure concentration. Total ATPase activity in the gill significantly increased at the lower exposure concentration of copper; although, it decreased at the higher exposure concentration (Figs. 1-3). Similarly, activities of Ca-ATPase and $\mathrm{Mg}$-ATPase $(\mu \mathrm{mol} \mathrm{Pi} / \mathrm{mg}$ prot./h) in the muscle of controls at day 0 were $2.50 \pm 0.53$ and $6.51 \pm 0.39$ respectively while these were $3.01 \pm 0.42$ and $6.49 \pm 0.68$ respectively at day 21. Ca-ATPase activity decreased only at the higher copper exposure especially after 14 . day while Mg-ATPase activity significantly increased at the lower copper exposure concentration and decreased at the higher exposure concentration. Total ATPase activity in the muscle significantly decreased at the higher exposure concentration (Figs. 4-6). Total protein concentrations in the gill and muscle did not change significantly $(\mathrm{P}>0.05)$ in any exposure groups (Figs. 7 and 8). Mean algae counts among control and $\mathrm{Cu}$ exposed mussels were $292,000 \pm 34,000$ algae $/ \mathrm{ml}$ and there was no significant difference $(\mathrm{P}>0.05)$ among the groups.

\section{Discussion}

No mussel mortality was observed after exposure to copper for 21 days, indicating that the copper concentrations used were sublethal for the animals. It was shown that similar copper concentrations were also reported to be sublethal for some other mussel species (Rajalakshmi \& Mohandas, 2005; Company et al., 2007; Zhou et al., 2021). However, taking the mortality as the end point of a study does not mean that animals are not affected by copper exposures. The present data demonstrated that despite alterations in ATPases activities following copper exposures, there was no significant

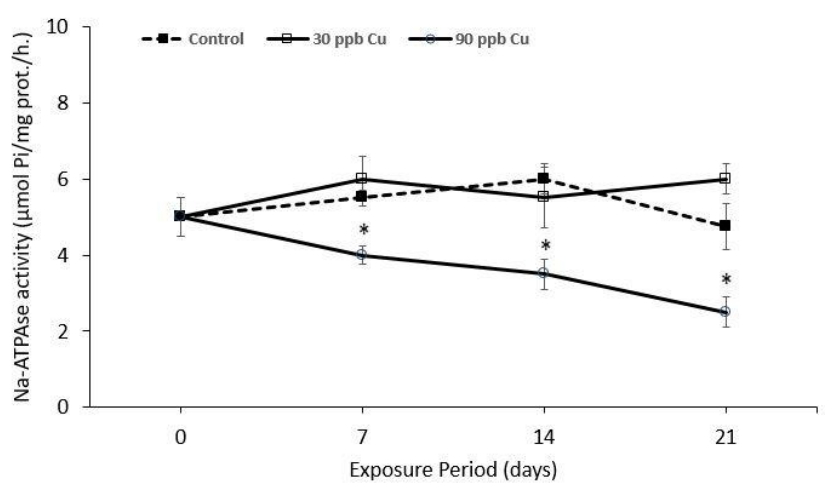

Figure 1. Activities of Na-ATPase in the gill of mussels (Unio tigridis) exposed to copper in differing concentrations and durations. Data demonstrate the mean and associated standard errors of 6 measurements. * indicates significant differences $(\mathrm{P}<0.05)$ among individual control group and its copper exposure groups.

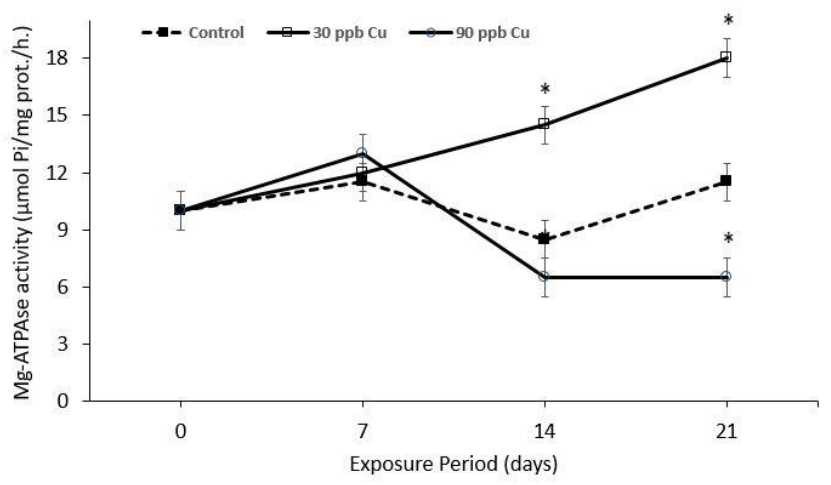

Figure 2. Activities of Mg-ATPase in the gill of mussels (Unio tigridis) exposed to copper in differing concentrations and durations. Data demonstrate the mean and associated standard errors of 6 measurements. * indicates significant differences $(\mathrm{P}<0.05)$ among individual control group and its copper exposure groups.

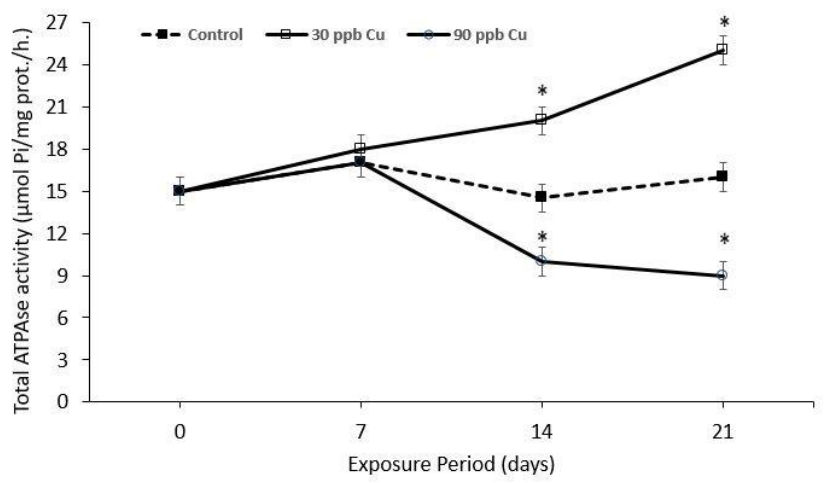

Figure 3. Activities of total ATPase in the gill of mussels (Unio tigridis) exposed to copper in differing concentrations and durations. Data demonstrate the mean and associated standard errors of 6 measurements. * indicates significant differences $(\mathrm{P}<0.05)$ among individual control group and its copper exposure groups.

changes in the appetite of mussels as algae consumption did not differ among exposure groups and controls. This suggests that low copper exposures affect ATPases but not filtration capacity of mussels. However, Jorge et al. (2013) found that filtration rate of juvenile freshwater mussels (Lampsilis siliquoidea) altered significantly following chronic Cu exposures. Similarly, Vijayavel et al. (2007) found significant alterations in the filtration rates of in the 
green mussel (Perna viridis) after exposure to Ag and Cr. There were significant decreases in all ATPase activities in both gill and muscle tissues indicating the metabolism of mussels responded to copper exposures and tried to cope with physiological stress. Nevertheless, alterations in ATPase activities were inevitable after copper exposures. Since freshwater mussels are a good bioindicator animal in the determination of water pollution, they have been frequently used in natural and laboratory studies using stress biomarkers (Doyotte et al., 1997; Falfushynska et al., 2018; Al-Fanharawi et al., 2019). There are some difficulties in doing chronic experiments with mussels. For example, supplying of a suitable food that mussels can filter easily is not easy and should be reproduced in laboratory conditions to prevent feeding experimental mussels with contaminated feed collected from the field.

Literature data demonstrated that ATPase activities in tissues of mussels altered by metal exposures, most important factors being metal types, concentrations, durations and biology of animals. Pagliarani et al. (1996) showed that both the $\mathrm{Na}, \mathrm{K}$-ATPase and $\mathrm{Na}$-ATPases in tissues of mussel (Mytilus galloprovincidis) showed dosedependent response to mercury ( 0.1 and $0.25 \mathrm{mg} / \mathrm{L})$, zinc ( 0.5 and $1.0 \mathrm{mg} / \mathrm{L})$, and ATPases being more susceptible to metals in the gills than in the mantle. Similarly, Viarengo et al. (1996) carried out an experiment on the same species, assessing in vivo effects of $\mathrm{Cu}$ on the $\mathrm{Ca}$ homeostasis mechanisms of gill cell plasma membranes after exposure to $\mathrm{Cu}$ for 1, 4, and 7 days. The activity of CaATPase and $\mathrm{Na}, \mathrm{K}-\mathrm{ATPase}$ on a plasma membraneenriched subcellular fraction showed an initial decrease reaching a minimum after four days of metal exposure, followed by a recovery. The authors indicated that the inhibition of the plasma membrane Ca-ATPase activity was a direct evidence of metal effects on Ca homeostasis processes while the inhibition of $\mathrm{Na}, \mathrm{K}$-ATPase could also involve an impairment of the $\mathrm{Na} / \mathrm{Ca}$ antiporter. Toxicity of metals seems more severe in young animals comparing to the older ones. Jorge et al. (2013) studied the effect of chronic $\mathrm{Cu}$ exposures on the juvenile freshwater mussels (Lampsilis siliquoidea) and found that there were several physiological disturbances during chronic copper exposure, predominant toxicity occurring as a decrease in whole body sodium content paralleled by an inhibition of Na,K-ATPase activity. Similarly, Giacomin et al. (2013) demonstrated that juvenile (6-12 months old) freshwater mussels (L. siliquoidea) were very sensitive to $\mathrm{Cu}$ exposures as whole-body ion contents $(\mathrm{Na}, \mathrm{K}, \mathrm{Ca}$ and $\mathrm{Mg}$ ) and enzyme (Na,K-ATPase, H-ATPase, and carbonic anhydrase) activities altered significantly. The effects of Cd exposures in the green-lipped mussel (Perna canaliculus) were demonstrated by Chandurvelan et al. (2013) after exposing the animals to acute and chronic exposures. They pointed out that following exposures, the levels of glycogen in the digestive gland and $\mathrm{Na}, \mathrm{K}$-ATPase activity in the gill were significantly altered by $\mathrm{Cd}$ exposure relative to levels in mussels exposed to Cd-free seawater. The effects of $\mathrm{Ag}$ and $\mathrm{Cr}$ were remarkable as the activities of $\mathrm{Na}, \mathrm{K}$-ATPase, Ca-ATPase, and Mg-ATPase in the mussels (Perna viridis) as inhibitions of enzymes were evident (Vijayavel et al., 2007). It is commonly agreed that chronic toxicity of $\mathrm{Cu}$ at sublethal levels was associated with ionoregulatory disturbance (Le et al., 2021). The authors indicated that $\mathrm{Cu}$ might inhibit $\mathrm{Na}, \mathrm{K}$-ATPase

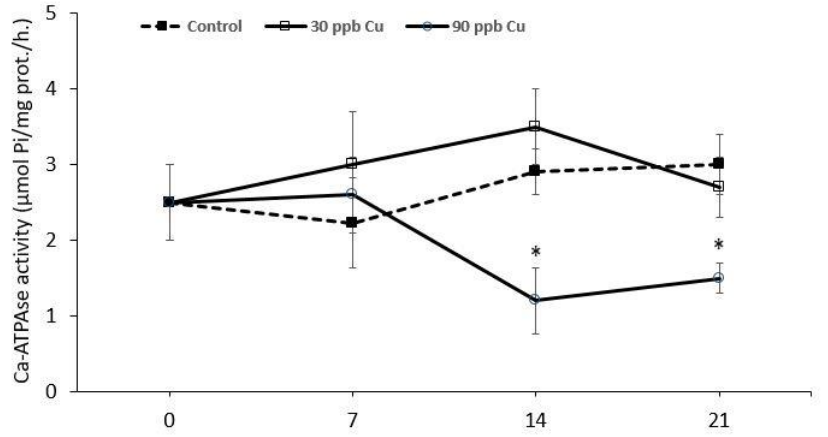

Figure 4. Activities of Ca-ATPase in the muscle of mussels (Unio tigridis) exposed to copper in differing concentrations and durations. Data demonstrate the mean and associated standard errors of 6 measurements. * indicates significant differences $(\mathrm{P}<0.05)$ among individual control group and its copper exposure groups.

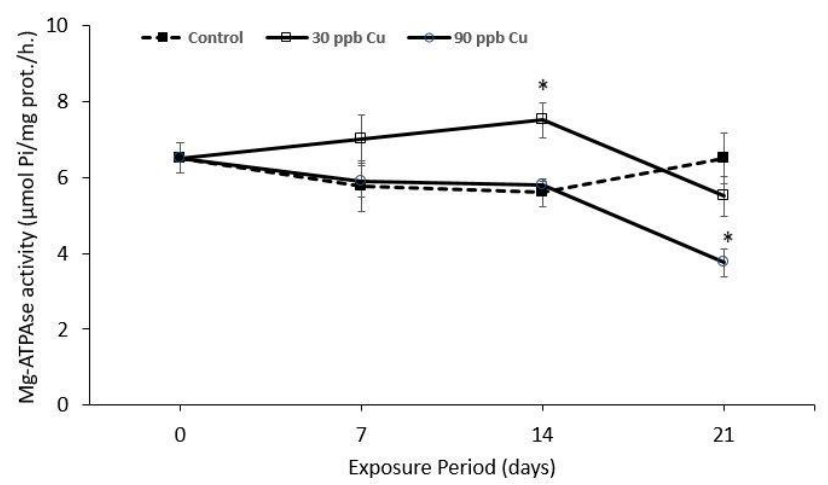

Figure 5. Activities of Mg-ATPase in the muscle of mussels (Unio tigridis) exposed to copper in differing concentrations and durations. Data demonstrate the mean and associated standard errors of 6 measurements. * indicates significant differences $(\mathrm{P}<0.05)$ among individual control group and its copper exposure groups.

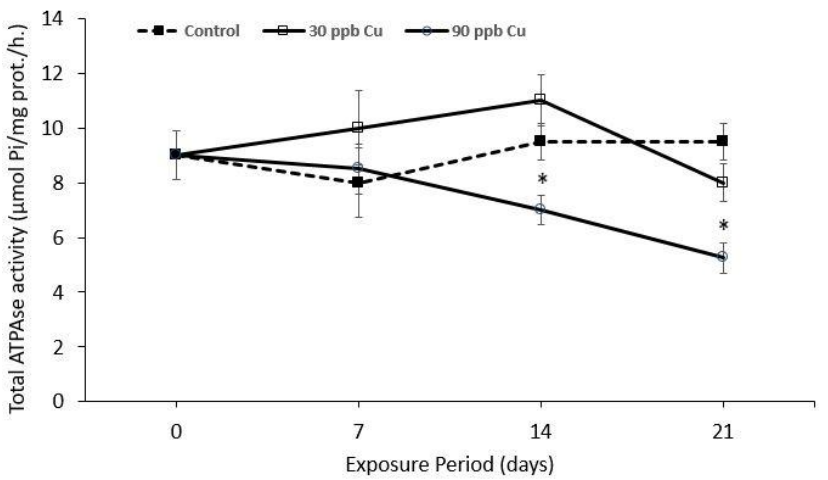

Figure 6. Activities of total ATPase in the muscle of mussels (Unio tigridis) exposed to copper in differing concentrations and durations. Data demonstrate the mean and associated standard errors of 6 measurements. * indicates significant differences $(\mathrm{P}<0.05)$ among individual control group and its copper exposure groups.

activity by reducing the number of functional pump sites and the limited $\mathrm{Cu}$-bound $\mathrm{Na}, \mathrm{K}$-ATPase turnover rate.

\section{Conclusion}

The present data demonstrated that ion ATPases of freshwater mussel (Unio tigridis) were very sensitive to copper exposures as their activities altered significantly following exposure to sublethal concentrations of copper. Nevertheless, algae filtration capacity of mussels did not 


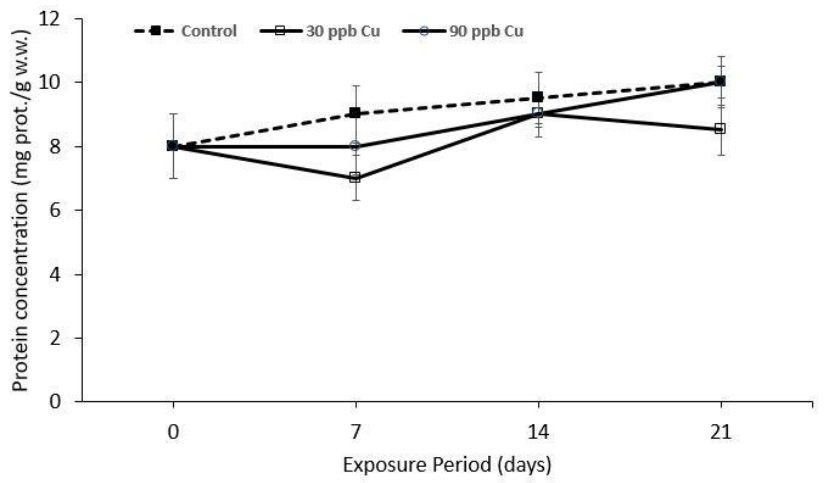

Figure 7. Levels of total protein in the gill of mussels (Unio tigridis) exposed to copper in differing concentrations and durations. Data demonstrate the mean and associated standard errors of 6 measurements. No significant difference $(\mathrm{P}>0.05)$.

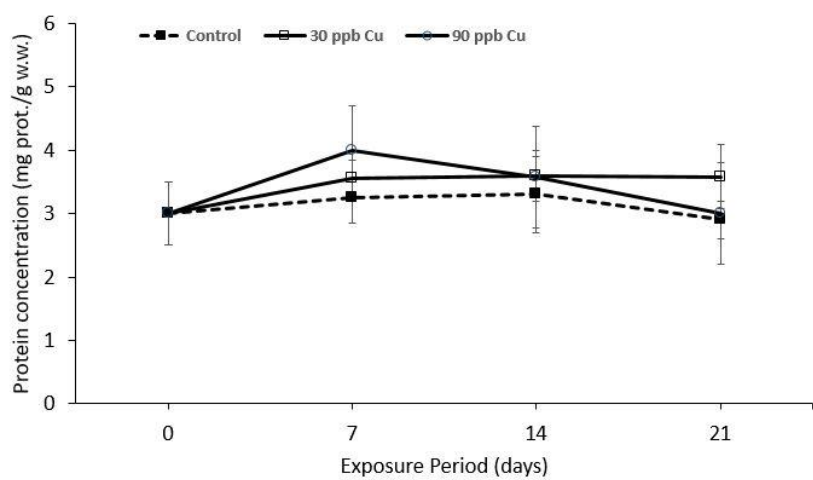

Figure 8. Levels of total protein in the muscle of mussels (Unio tigridis) exposed to copper in differing concentrations and durations. Data demonstrate the mean and associated standard errors of 6 measurements. No significant difference $(P>0.05)$.

change significantly after 21 days of exposure durations. This was found to be significant in terms of emphasizing the chronic damage that may occur in mussels exposed to metals in natural aquatic environments. Although metal concentrations are generally at very low levels in many natural aquatic environments, the present study emphasized the environmental awareness once again due to the toxic effects of $\mathrm{Cu}$ at very low levels. As a continuation of this study, copper toxicity in mussels can be examined from different aspects such as the transport of metals in the food-chain.

Acknowledgements: I would like to thank to Dr. Uslu for the help in algae culturing. Experimental parts of this study were carried out in Biology Department of Çukurova University. So my thanks go to Dr. M. Canli for allowing me to carry out the experiments in his laboratory.

Ethics committee approval: Ethics committee approval is not required for this study.

Conflict of interest: The author declares that there is no conflict of interest.

\section{References}

Al-Fanharawi, A.A., Rabee, A.M., \& Al-Mamoori, A.M. (2019). Multibiomarker responses after exposure to organophosphates chlorpyrifos in the freshwater mussels Unio tigridis and snails Viviparous benglensis. Human and Ecological Risk Assessment: An International Journal, 25(5), 1137-1156. https://doi.org/10.1080/10807039.2018.1460800

Atkinson, A., Gatemby, A.O., \& Lowe, A.G. (1973). The Determination of inorganic ortophosphate in biological systems. Biochimica Et Biophysica Acta, 320, 195-204. https:/ / doi.org/10.1016/0304-4165(73)90178-5
Canli, M., \& Stagg, R.M. (1996). The effects of in vivo exposure to cadmium, copper and zinc on the activities of gill ATPases in the Norway lobster, Nephrops norvegicus. Archives of Environmental Contamination and Toxicology, 31(4), 494-501. https://doi.org/10.1007/BF00212433

Canli, E.G., Celenk, A., \& Canli, M. (2021). Accumulation and distribution of nanoparticles $\left(\mathrm{Al}_{2} \mathrm{O}_{3}, \mathrm{CuO}, \mathrm{TiO}_{2}\right)$ in tissues of freshwater mussel (Unio tigridis). Bulletin of Environmental Contamination and Toxicology (in press). https:// doi.org/10.1007/s00128-021-03410-5

Canli, E.G., \& Canli, M. (2021). Characterization of ATPases in the gill of freshwater mussel (Unio tigridis) and effects of ionic and nanoparticle forms of aluminium and copper. Comparative Biochemistry and Physiology Part C: Toxicology \& Pharmacology, 247, 109059. https://doi.org/10.1016/j.cbpc.2021.109059

Chandurvelan, R., Marsden, I.D., Gaw, S., \& Glover, C.N. (2013) Biochemical biomarker responses of green-lipped mussel, Perna canaliculus, to acute and subchronic waterborne cadmium toxicity. $\begin{array}{lll}\text { Aquatic Toxicology, 303-313. } & \text { 140, }\end{array}$ https://doi.org/10.1016/j.aquatox.2013.06.015

Clark, R.B. (1989). Marine pollution. Oxford: Oxford Scientific Publications, Clarendon Press.

Company, R., Serafim, A., Cosson, R.P., Fiala-Médioni, A., Camus, L., Colaço, A., \& Bebianno, M.J. (2008). Antioxidant biochemical responses to long-term copper exposure in Bathymodiolus azoricus from MenezGwen hydrothermal vent. Science of Total Environment 389(2-3), 407-417. https://doi.org/10.1016/j.scitotenv.2007.08.056

Doyotte, A., Cossu, C., Jacquin, M.C., Babut, M., \& Vasseur, P. (1997). Antioxidant enzymes, glutathione and lipid peroxidation as relevant biomarkers of experimental or field exposure in the gills and the digestive gland of the freshwater bivalve Unio tumidus. Aquatic Toxicology, 39(2), 93-110. https://doi.org/10.1016/S0166$\underline{445 X(97) 00024-6}$

Falfushynska, H.I., Gnatyshyna, L.L., Ivanina, A.V., Sokolova, I.M., \& Stoliar, O.B. (2018). Detoxification and cellular stress responses of unionid mussels Unio tumidus from two cooling ponds to combined nano-ZnO and temperature stress. Chemosphere, 193, 1127-1142. https://doi.org/10.1016/j.chemosphere.2017.11.079

Giacomin, M., Gillis, P.L., Bianchini, A., \& Wood, C.M. (2013). Interactive effects of copper and dissolved organic matter on sodium uptake, copper bioaccumulation, and oxidative stress in juvenile freshwater mussels (Lampsilis siliquoidea). Aquatic Toxicology, 144, 105-115. https:// doi.org/10.1016/j.aquatox.2013.09.028

Goswami, P., Hariharan, G., Godhantaraman, N., \& Munuswamy, N. (2014). An integrated use of multiple biomarkers to investigate the individual and combined effect of copper and cadmium on the marine green mussel (Perna viridis). Journal of Environmental Science and Health, $\begin{array}{llll}\text { Part A, 49(13), } & \text { 1564-1577. }\end{array}$ https://doi.org/10.1080/10934529.2014.938534

Jorge, M.B., Loro, V.L., Bianchini, A., Wood, C.M., \& Gillis, P.L. (2013). Mortality, bioaccumulation and physiological responses in juvenile freshwater mussels (Lampsilis siliquoidea) chronically exposed to copper. Aquatic Toxicology, 126, 137-147. https://doi.org/10.1016/j.aquatox.2012.10.014

Le, T.Y., Nachev, M., Grabner, D., Garcia, M.R., Balsa-Canto, E., Hendriks, A.J., \& Sures, B. (2021) Modelling chronic toxicokinetics and toxicodynamics of copper in mussels considering ionoregulatory homeostasis and oxidative stress. Environmental Pollution, 287, 117645. https://doi.org/10.1016/j.envpol.2021.117645

Lowry, O.H., Rosebrough, N.J., Farr, A.L., \& Randall, R.J. (1951). Protein measurement with the Folin phenol reagent. Journal of Biological Chemistry 193(1), 256-275.

Nugroho, A.P., \& Frank, H. (2012). Effects of copper on lipid peroxidation, glutathione, metallothionein, and antioxidative enzymes in the freshwater mussel Anodonta anatina. Toxicological \& Environmental Chemistry, 94(5), 918-929. https://doi.org/10.1080/02772248.2012.675156

Pagliarani, A., Ventrella, V., Trombetti, F., Pirini, M., Trigari, G., \& Borgatti, A.R. (1996). Mussel microsomal $\mathrm{Na}^{+}-\mathrm{Mg}^{2+}$-ATPase sensitivity to waterborne mercury, zinc and ammonia. Comparative Biochemistry and Physiology Part C: Pharmacology, Toxicology and Endocrinology, 113, 185191. https://doi.org/10.1016/0742-8413(95)02086-1

Rajalakshmi, S., \& Mohandas, A. (2005). Copper-induced changes in tissue enzyme activity in a freshwater mussel. Ecotoxicology and Environmental Safety, 62(1), 140-143. https:// doi.org/10.1016/j.ecoenv.2005.01.003

Sukhovskaya, I.V., Borvinskaya, E.V., Kochneva, A.A., Slukovsky, Z.I., Kurpe, S.R., Xu, K., ... \& Li, C. (2021). Biochemical and metabolic responses of the deep-sea mussel Bathymodiolus platifrons to cadmium and copper exposure. Aquatic Toxicology, 236, 105845. https://doi.org/10.1016/j.aquatox.2021.105845 
Viarengo, A., Pertica, M., Mancinelli, G., Burlando, B., Canesi, L., \& Orunesu, M. (1996). In vivo effects of copper on the calcium homeostasis mechanisms of mussel gill cell plasma membranes. Comparative Biochemistry and Physiology Part C: Pharmacology, Toxicology and Endocrinology, 113(3), 421-425. $\quad$ https://doi.org/10.1016/07428413(96)00004-7

Vijayavel, K., Gopalakrishnan, S., \& Balasubramanian, M.P. (2007) Sublethal effect of silver and chromium in the green mussel Perna viridis with reference to alterations in oxygen uptake, filtration rate and membrane bound ATPase system as biomarkers. Chemosphere 69(6), 979-986. https:// doi.org/10.1016/j.chemosphere.2007.05.011

Zhou, L., Li, M., Zhong, Z., Chen, H., Wang, X., Wang, M., \& Li, C. (2021). Biochemical and metabolic responses of the deep-sea mussel Bathymodiolus platifrons to cadmium and copper exposure. Aquatic Toxicology, 236, 105845. https:/ / doi.org/10.1016/j.aquatox.2021.105845

Wood, C.M., Farrell, A.P., \& Brauner, C.J. (2012a). Homeostasis and toxicology of essential metals. Fish Physiology 31A. Academic Press, London pp 497.

Wood, C.M., Farrell, A.P., \& Brauner, C.J. (2012b). Homeostasis and toxicology of non-essential metals. Fish Physiology 31B. Academic Press, London pp 507. 